\title{
Eşinden Ayrılmış Annelerin Görüşü Açısından Çocuklarının Sorunları
}

\author{
Hakan Uşaklı* \\ Sinop Üniversitesi Ĕ̆itim Fakültesi, Sinop
}

\begin{abstract}
Öz
Boşanma tüm dünyada artan bir durum olarak en fazla çocuklarn etkilemektedir. Bu çalışmada eşinden ayrılmış ve ilkokulda çocuğu olan annelerle çocuklarının problemleri üzerine görüşülmüştür. Çalışma nitel araştırma yöntemiyle yürütülmüştür. Sinop'ta yedi farklı ilkokulda araştırma yürütülmüştür. Çalışma grubunda eşinden ayrılmış gönüllü elli anne yer almıştır. Yapılan çalışmalar tek ebeveynli çocukların geniş kapsamlı sorunları olduğunu ortaya koymaktadır. Bu çalışma sonunda eşinden ayrılmış anneler, çocuklarının duygusal, davranışsal ve zihinsel temalar kapsamında gruplandırılan sorunlarının olduğunu belirtmişlerdir. Okul yöneticileri, öğretmenler ve danışman uzmanlar parçalanmış ailelerden gelen çocukların sorunlarına daha dikkat etmelidir. Eşinden ayrılmış annelerin çocuklarıyla olan ilişkilerinde uzman yardımı almaları önemlidir. İlerde yapılacak araştırmalarda boşanmanın çocukların yaş grupları ve cinsiyetleri açısından problemlerinde farklılık oluşturup oluşturmadı̆̆̆ konuları incelenebilir.
\end{abstract}

Anahtar sözcükler: Boşanma, Boşanmış anneler, Tek ebeveynli çocukların sorunları

\section{The Problems of Children in terms of Divorced Mothers}

\begin{abstract}
Divorce, as an increasing issue in all around the world, mostly affects to children. In this study, the problems of mothers who divorced from their husbands and their children were interviewed. The study conducted as qualitative research method. The study was conducted in seven different elementary schools in Sinop. In the study group, there were fifty volunteers divorced mother as participants. Researches point out that the single parent children have very wide range of problems. At the end of this study, divorced mothers concluded their children's problems in three group themes such as emotional, behavioral and cognitive. School administrators, teachers and counselors should be aware of single parents' children problems. It is important that divorced mothers should take professional help about their relations with their children. It is recommended that future studies can investigate the effects of divorce on differentiation of problems according to children's age and sex.
\end{abstract}

Key Words: Divorce, Single mothers, Problems of single parents' children

\section{Giriş}

Günümüzde boşanma oldukça sıradan bir olay olmuştur. Amerika Birleşik Devletlerinde her yeni iki evlilikten biri boşanmayla sonuçlanmaktadır ve bu durum son otuz yıldır bu şekilde devam etmektedir (Schaie ve Willis, 1996). Avrupa'da da boşanma oranının son yirmi yılda benzer şekilde arttığı görülmektedir (Jonsson ve diğerleri, 2000: 101).

\footnotetext{
*Yazışma adresi. Email: husakli@yahoo.com
} 
Aile ortak bir geçmişi, birlikteliği paylaşan, duygusal bağı olan, bireysel aile üyelerinin ve ailenin bütününün ihtiyaçlarını karşılamak için eylem planlayan bireylerden oluşmuş karmaşık toplumsal bir yapı olarak tanımlanır (Nazlı, 2003). Aile, çocuklara toplusal gelişim, uyum, sosyalleşme konusunda rehberlik eden etkili kurumlardan biridir (Yavuzer, 2001). Feldman ve Wentzel (1990) ailelerin çocuklarına verecekleri çocuk merkezli eğitim sayesinde onların sosyal kabul görmelerini sağlayabileceklerini belirtmektedirler. Toplumsal yapının en küçük birimini oluşturan çekirdek aile bazen anne baba ve çocukların bir arada olduğu kurum olarak görülmeye bilir. Farklı nedenlerden dolayı aile işlevini tam olarak yerine getiremez ve sonuç olarak kötü bir duruma sebep olabilir (Şentürk, 2006). Ölüm, boşanma, geçici ve sürekli ayrılıklar sebebiyle bilinen aile şeklindeki değişmeler parçalanmış ya da tek ebeveynli aile olarak adlandırılmaktadır (Soyaslan, 1998). Şentürk (2006) ailenin bazı sebeplerden dolayı parçalanmış yapısıyla kendisinden beklenen sorumlulukları yerine getiremeyeceğini ifade eder.

Parçalanmış veya tek ebeveynli ailede yetişen çocuklar toplumsallaşma görevlerini yerine getirmede başarısızdır (Uluğtekin, 1991). Ailede geçimsizliğin yarattığı şiddetli çatışma anne ve baba arasındaki ilişkiyi zayıflatarak boşanmaya neden olmaktadır ve bu boşanmaların sonucu olarak çocuklarda yüksek kaygı, saldırganlık, çekingenlik gibi bir takım anti sosyal davranışlar gözlenmektedir (Uluğ ve Candan, 2008). Tek ebeveynden yeteri kadar destek ve sevgi göremeyen çocuk bu ihtiyacını sürekli sergileme yoluna gidecektir (Yörükoğlu, 2004).

Parçalanmış aileye mensup olan çocuk sürekli iç çatışma içindedir. Bu çatışmalar sonunda çocuk ailesini suçlayarak onlara karşı bir tavır sergiler (Wolf, 1998). Sorunlarını çözme yeteneğinden yoksun çocuk anti sosyal davranışlarını çözemediği için ileride de daha derin sorunlarla yüz yüze gelebilecektir (Morganett, 2005). Boşanmanın çocuklar üzerine depresyon, stres, yalnızlık, hırçınlık, dikkat toplayamama gibi olumsuz sonuçlar doğurduğu araştırmalarla ortaya konulmuştur (Herwig ve diğerleri, 2004; Jockson, 2000).

Yurt dışında yapılmış çalışmalarda boşanmanın çocuklar üzerine olan olumsuz etkileri şu şekilde özetlenebilir: Shelton (1969) boşanmanın çocuklarda düşük akademik başarıya yol açtığını belirtir. Wallerstein ve Kelley (1980) ise boşanmanın çocuklarda kaygıyı tetiklediğini iddia etmiştir. Babası olmayan çocukların benlik saygıları oldukça düşüktür (Blake, 1981). Annesi ya da babasından ayrı yaşayan çocuklarda davranış problemleri, anksiyete, üzüntü, fobi, depresyon gibi duygusal, düşük okul başarısı gibi bilişsel, saldırganlık, çekingenlik gibi davranışsal problemler, alkol, narkotik, depresyon, aile ile çatışma gibi sorunların ortak görülebildiği araştırmalarla ortaya konulmuştur (Block ve diğerleri, 1986; Kalter ve diğgerleri, 1985; Frost ve Pakiz, 1990; Amato ve Keith, 1991; Liu, 2003).

Ülkemizde parçalanmış ailelerin çocuklarının durumlarını gösteren çalışmalardan bazıları ise şunlardır: Karaoğlan (1997) boşanma çocukların kişiliklerini olumsuz etkilediğini belirtmiştir. Bu çocuklar mutsuz olmanın yanı sıra sigara, alkol ve uyuşturucu kullanmaya eğilimlidirler. Boşanma çocukların benlik saygısını olumsuz 
etkilemekle birlikte davranış ve uyum sorunları oluşturur, ayrıca depresyona yol açar ve boşanmış ailelere mensup çocuklar daha fazla sosyal desteğe ihtiyaç duyarlar (Çelikoğlu, 1998; Kuyucu, 1999; Şirvanlı-Özen, 1998; Erim, 2001; Elmac1, 2001). Problem çözme becerisi düşük olan boşanmış ailelere mensup çocukların suça daha fazla yönelimli oldukları belirtilmektedir (Özcan, 2005; Akduman ve diğerleri, 2007).

Okullarda anne baba ayrı yaşayan öğrenciler bulunduğu gibi anne baba ayrı olmasa bile baba bir şekilde özellikle çalışma amacıyla gurbette olan öğrencilerin de olduğu bilinmektedir. Yapılan bazı gözlemlerde, bu öğrencilerde bir takım davranış bozuklukları çoklukla göze çarpmaktadır. Bunlardan bazıları şu şekilde sıralanmaktadır: Gruplaşmalar, saldırgan tutum ve davranışlar sergileme mevcuttur. $\mathrm{Bu}$ tutumlar bu tarz öğrencilerin sıklıkla sergilediği davranışlardır. Bazı okul öğrencileri daha çok ekonomik anlamada yetersiz ve boşanmış aile çocuklarından oluştuğu için bu tarz problemlere sıklıkla rastlanabilmektedir. Saldırgan, sinmiş, aşırı karamsar öğrenciler gözlenebilmektedir. $\mathrm{Bu}$ öğrencilerin ortak durumuna göre müdahalede bulunulması gerekmektedir (Uşaklı, 2011). Yapılan bir çalışmada parçalanmış ailelere mensup ilkokul çağı çocuklarının sorunlarının belirlenmesi ve bu sorunlardan davranışa ilişkin olanlarına yönelik müdahale çalışmasında Uşaklı (2011), bazı temel sorunların mücadelesinde bireysel psikolojik danışma, grupla psikolojik danışma ve dramayı önermiştir.

Parçalanmış ailelere mensup olan çocuklar sıklıkta bir takım karmaşık ve istenmeyen duygular yaşarlar. Bu duygular korku, üzüntü, öfke, suçluluk, yalnızlık ve reddedilmedir (Benedek ve Brown, 1997; Thomas ve Waddell, 1990; Weyburne, 2000; Wolf, 1998). İlkokula giden küçük yaş grubu çocuklar boşanma olayından sonra ebeveynleri suçlama, kızgınlık, üzüntü, söz dinlememe, içe kapanma, başarısızlık ve kıskançlık gibi istenmeyen davranış sergileyebilirler (Özgüven, 2001). Çocuklar boşanmadan dolayı suçlayacak birilerini ararlar ve bu kişi evde bulunan anne ya da babalardır (Ekşi, 1990).

Sağlıklı aile ortamının çocuklar için önemi tartışılmazdır. Çalışmalar anne baba arasındaki kaliteli ilişkinin ve olumlu ev ortamının aile ve çocuklar için oldukça önemli olduğunu ortaya koymaktadır (Amato, 2005).

Ekonomik sorunlarda parçalanmış ailelerin karşılaştıkları başka bir durumdur. Tek ebeveynli ailelerin yaşadıkları ekonomik güçlükler, ebeveynin öğrenim düzeyi ve ailenin gelir düzeyi açısından, yaşamdan duydukları tatmin ise ebeveynin öğrenim düzeyi, ailenin aylık gelir düzeyi ve evde yaşayan kişi sayısı açısından anlamlı farklılıklar göstermektedir (Öztürk, 2012).

Parçalanmış ve düşük gelire sahip ailelere mensup çocuklar daha çok problem davranışlar ve depresif semptomlar sergilemeye eğilimlidir. Ayrıca bu çocuklar diğer normal ailelerden gelen yaşıtlarına göre daha düşük sosyal yeterlilik gösterirler (Moore ve diğerleri, 2006).

Mutlu evlilikler çocukları da mutlu kılmaktadır. Ortalama olarak tek ebeveynli bir aileye mensup çocuklar iki ebeveynli ailelerden gelen çocuklara kıyasla depresyon 
sosyal ve davranışsal problemleri daha fazla sergilemektedirler. Biyolojik anne ve baba ortamında daha az çatışmalı evliliklerde yetişen çocuklar ileriki yaşlarında daha sağlıklı ve mutlu olmaktadırlar (www.childtenrs.org).

Doğuştan beri anne ve babasıyla yetişen çocuklar tek ebeveynli yaşıtlarına nazaran \%80 daha iyi bilişsel ve davranışsal yeteneklere sahiptirler (Carlson ve Corcoran, 2001). Çocuk gelişiminde babanın rolüne genel bir bakış çalışmasında Lamb (1997), sosyal desteğin, ekonomik yardımın azaldığı, çocukların terk edilme duygusunu algıladıkları eşinden ayrı annelerin duygusal sıkıntı çektiğini belirterek, baba yokluğunun çocuklar için kötü sonuçlar ortaya koyduğunu özetlemiştir. Aile yapısı ve çocukların davranışlarına ilişkin çalışmada, eğitimsel başarı ve uyum ölçümlerinde iki ebeveynli ailelere mensup çocukların tek ebeveynli olanlara göre daha yüksek puan aldıklarını ortaya koymaktadır (Jaffee ve diğerleri, 2003: 109).

Tek ebeveynli çocuklar ile iki ebeveynli çocuklardaki bu farkın sebebi öncelikle sosyoekonomik yapı farklılıklarından kaynaklanmaktadır. Çünkü tek anneler daha düşük eğitimsel gelişim gösterme, daha az sosyal destekleri ve psikolojik iyi olma hallerine sahiptirler (Carlson ve Corcoran, 2001; Dunn, Deater-Deckard, Pickering, ve O'Connor, 1998; McLanahan ve Sandefur, 1994; O'Connor, Dunn, Jenkins, Pickering, ve Rabash, 2001).

Sosyoekonomik yapıya dayanarak araştırmacılar aile yapısıyla okul bırakma, ergen hamileliği ve işsizlik ile aile yapısı arasında \%50 bağ bulmuşlardır. Bu da tek ebeveynli ailelerin iki ebeveynlilere göre daha az ekonomik gelirlerinin olmasının bir sonucudur (McLanahan ve Sandefur, 1994).

Bir meta analizinde babasızlık ve çocukların durumları üzerine 63 çalışmayı inceleyen Amato ve Gilberth (1999), babaları otoriter bir ebeveynlik sergileyen ailelere mensup çocuklarda daha az davranış problemleri sergilediklerini, akademik açıdan daha başarılı oldukları sonucuna ulaşmıştır. Tek ebeveynli çocuklar artmış psikiyatrik hastalık riski, intihar ya da intihar girişimi, yaralanma ve bağımlılık göstermektedirler. Sosyoekonomik durum ve ebeveynlerin bağımlılı̆̆ı ya da ruhsal hastalık gibi karşılıklı faktörler için düzeltme yapıldıktan sonra tek ebeveynli çocukların iki ebeveynlilere oranla psikiyatrik hastalığa yakalanma, çocukluk dönemi intihar girişimi, alkol ile ilgili rahatsızlıklar ve uyuşturucuyla ilişkili hastalıklara yakalanma riskleri daha yüksektir. Tek ebeveynli erkek çocuklar kızlara göre alkol ve narkotikle ilişkili hastalıklara yakalanma ve ölüm risklerinin daha fazla olduğu görülmektedir. Tek ebeveynli ailelerde yetişen çocukların sağlıkları açısından olumsuz durumlar yaratmaktadır. Bunun sebebi ise hane halkı kaynaklarının eksikliği risk artışında önemli rol oynar. Ancak, demografik ve sosyoekonomik koşullar geniş bir yelpazede çok değişkenli modellere dahil olsa bile, tek ebeveynli ailelere mensup çocukların ölüm, sakatlık ve yaralanma olasılı̆̆ yüksektir (Weitoft ve diğerleri, 2003).

Ailevi durum, depresyon, anksiyete ve problem davranışlar ile düşük gelirli tek ebeveynli, boşanmış annesi olan çocuklar arasında güçlü bir ilişki vardır (Buckner ve Bassuk, 1999). Tek ebeveynli ailelerden gelen çocuklar okullarda oldukça başarısız olmaktadır. Tek ebeveynli çocuklar okullarda azınlık grubu oluşturmakta ve 
istenmeyen davranışlar sergileyerek diğer çocuklara zarar vermektedir. Amerika Birleşik Devletlerinde 14 eyalette 18000 çocuk üzerine yapılan araştırmada parçalanmış ailelerden gelen çocukların \%40'1 düşük başarılıdır. Bu çocuklar okullarından her yıl uyarı ya da uzaklaştırma cezaları almaktadır (Savage, 1980).

Araştırma sonuçları iki ebeveynli ailelere mensup çocukların ölçümlerinde daha az dışa dönük davranış ve hiperaktivite sergilediklerini göstermektedir. Araştırmalar aile yapısıyla çocuk cinsiyetine göre davranışların ilişkili olduğu görülmektedir. Bu duruma göre eşinden ayrı anne kızlarının daha çok dişa dönük davranış ve hieperaktivite sergilediklerini göstermektedir. Ancak erkek çocukların problemlerinde aileleri açısından farklılık yoktur. Aile yapısı içinde ebeveyn uygulamaları ve çocukların cinsiyeti üzerine farkı çalışmalara ihtiyaç vardır (Mokrue ve diğerleri, 2012).

Tek ebeveynli aileler daha düşük pro-aktif öğretim, izleme ve akademik tutum sergilediklerini, bu ailelere mensup çocukların okullarda performanslarının kötü olduğu IQ'larının düşük olduğu ve akranları tarafından sevilmedikleri belirtilmektedir (Pettit ve diğerleri, 2009). Düşük eğitimli dul anneler çocukları açısından olumsuz sonuç doğururlar. Ancak çocuğun cinsiyeti, çocuk sayısı, sırası, çalışma takvimi açısından bu tek gösterge sonuçları doğur değildir. Sonuç olarak, politika yapıcıları hazlı sonuçlara karşı dikkatli olmalıdırlar. Ölçümlerin objektif olduğu sonuçlara ihtiyaç duyulmaktadır (Ghysels ve diğerleri, 2008).

Belirgin olarak iki ebeveynle de yaşamıyor olmak on dört yaşındaki çocuklara olumsuz sonuçlar yol açar (Sandefur ve diğerleri, 1992). İki ebeveynli çocuklar her zaman tek ebeveynli yaşıtlarına göre avantajlı durumdadırlar (Demo ve diğerleri, 1996).

Ergenlikte gelişim ile ilgili çoğu teoriler çok fazla ilgi özellikle akran grup yakınlaşması ve arkadaşlık ilişkileri ailelerin daha az rolünü önerdiğini vurgular. Çünkü ergenler aileden bağımsız ve mesafeli olmayı ister (Bell, 1981; Douvan ve Adelson, 1966; Youniss ve Smollar, 1985). Ergenlikte aile ergen anlaşmazlığı (Collins, 1990; Montemayor, 1986) ve akran ve çok yakın katılımı artırarak ergenlikte iyi bir yaşam aşaması olabilir. Ama bulgular sosyo-duygusal, akademik ve küresel ergen olmayı şekillendirmede anne ile olan ilişkinin temel rolünün önemini ortaya koyar. Ergen gelişiminde diğer durumların önemli olduğu kadar bu sonuçlar aile üyelerinin ilişkisini doğrular.

Warshak (2000), Wallerstein (1980: 89) “erken pozisyonu değiştirme” önerisini tartışmış ve babanın katkısının oldukça fazla olduğunu belirtmiştir. Wallerstein ve diğerleri., (2000) ve Wallerstein ve Lewis, (1998)'in araştırmaları ışı̆̆ında boşanmadan sonra babaları ile birlikte kalan çocukların yaşamlarının çok da iyi olmadığını belirtmektedirler. Boşanmış babalar çocuklarıyla birlikte olmakta zorlamak onları çocuklarıyla olmaları için baskı altına almak çocuğa zararlı olabilmektedir. Babadan beklenen okul masraflarını karşılamasıdır. 
Boşanmanın çocuklar üzerine olumsuz etkisi: 25 yıllık bir çalışma raporu başlıklı araştırmada, 1960lardan 1980lere kadar boşanmada bir ivme yaşandığı geleneksel olmayan aile sayısının (örneğin tek eşli veya aynı cinsiyetten yapay aile) arttığı gözlenmiştir. Boşanma çocukların duygusal uyum, cinsel yönelim ve anti sosyal davranışlarına olumsuz etkide bulunmaktadır (Demo ve Acock, 1988). Sadece annenin olduğu ailelere mensup çocukların yetişkinlikte zayıf karakter göstermektedir. İlerde kendileri de tek ebeveynli olma eğilimindedirler. Boşanma ekonomik fakirlik, ebeveyn uygulamaları, komşu şartları, düşük sosyoekonomik seviyeye yol açmaktadır (McLanahan ve Booth, 1989).

Yapılan çalışmalar ışığında boşanma üzerine gelişimsel değerlendirmeler şu şekilde özetlenebilir. Tek ebeveynli ailelerde;

3 ile 5 yaş çocuklarda;

- Aile durumuna ilişkin zayıf anlayış

- Duygular: korku ve güvensizlik

- Kâbuslar, sızlanma, ağlama, bağlanma davranışları

- Çabuk öfke nöbetleri

- Yeme ve uykuda değişmeler

- Gerileme bebek benzeri davranış

6 ile 8 yaş çocuklarda;

- Kendi ihtiyacını belirlemede güçlük

- Üzgün, kayıp, korku, belirsizlik hissi

- Yaygin anksiyete

- Dikkat toplayamama ve tedirginlik

- Okul çalışma problemleri

- Terk duyguları, ebeveynleri özlem onları fazla görememe

- Algilanan reddedilmeye öfke duyma

- Koruyucu aileye, öğretmene ve diğer çocuklara saldırı

- Reddedilme, kendini suçlama, yabancılaşmış hissi

- Güvenlik için diğer yetişkinlere bağlanma

9 ile 12 yaş çocuklarda

- Kaybolma hissi

- Reddedilmiş, çaresiz, yalnız, utanma, sıkılma hissi

- Ebeveyn benzeri davranış kontrolünde güçsüzlük

- Öfke, çekinme, aşırı aktiflik 
- Boşanmadan dolayı bir ebeveyni suçlama doğrudan öfke

- Okul çalışma problemleri

- Karmaşık düşünceler, yalnızlık, depresyon duygularıyla mücadele

- Otoriteyle güç mücadelesi

- Ev dişındaki diğer yetişkinlerden destek arayabilme gibi duygu ve davranışlar görülebilmektedir (O’Rourke ve Worzbyt, 1996; Baris ve Garrity, 1988; Johnson ve Roseby, 1997; Wallerstein ve Blakeslee, 2003).

Boşanma ülkemizde de artan bir durumdur. 2010 yılının III. Döneminde (Temmuz, Ağustos, Eylül) 175.711 çift evlenmiştir. 2010 yılının III. Döneminde 23.527 çift boşanmıştır. 2010 yılının III. Döneminde meydana gelen boşanmaların \% 40'1 evliliğin ilk 5 yılı içinde, \%23,5'i ise 16 yıl ve daha fazla süre evli olan çiftlerde gerçekleşmiştir (TÜİK, 2010). Sinop il merkezinde parçalanmış ailelerin çocuklarına yönelik olarak yapılacak çalışmalar onların topluma kazandırılması ve diğer çocuklara olumsuz etki göstermemeleri açısından oldukça önemlidir. Boşanmış annelerin çocuklarıyla yaşadıkları sorunları bilmek onlara rehberlik etme açısından oldukça önemlidir.

Bu çalışmada Sinop'ta eşlerinden ayrılmış ilkokulda (6-12 yaş grubu) okuyan çocuğu olan elli annenin boşanmadan dolayı çocuklarında gözlemledikleri sorunları ortaya çıkarmak amaçlanmıştır. Genel olarak dünyada ve Türkiye'de özel olarak Sinop'ta da görülen boşanmanın olumsuz etkilerinin eşinden ayrı annelerin gözüyle değerlendirmek çalışmanın amacı içindedir.

Çalışma Sinop'ta çocukları yedi farklı ilkokulda okuyan elli anneyle sınırlandırılmıştır. Çalışmaya katılan eşlerinden ayrılmış annelerin çocukları altı ile on iki yaşlar arasında toplanmaktadır.

\section{Yöntem}

$\mathrm{Bu}$ araştırmada nitel araştırma yöntemi kullanılmıştır. Araştırma, 2012-2013 öğretim yılında Sinop il merkezinde yer alan ve şehrin çeşitli bölgelerinde tesadüfi seçilmiş 7 ilkokulda çocukları olan boşanmış anneler üzerinde uygulanmıştır. Araştırmada veri toplama aracı olarak, boşanmış annelerin çocuklarında gözlemledikleri problemleri belirlemek amacıyla, araştırmacı tarafından geliştirilen yarı yapılandırılmış mülakat formu kullanılmıştır. Nitel araştırmada yarı yapılandırılmış mülakat soruları ile elde edilen verilerin çözümlenmesinde içerik analizi kullanılmıştır. İçerik analizi uygulanan verilerin güvenirliğinin hesaplanması için verilerden belli bir miktar veri alınıp iki farklı zamanda aynı metnin kodlanması ile gerçekleştirilmiştir. Kategoriler arasında uyumun \%81 düzeyinde olduğu bulunmuştur. Frekans ve yüzdeleri hesaplanarak veriler tablolaştırılmıştır.

Araştırmanın örneklemini eşlerinden ayrılmış ilkokulda (6 ile 12 yaşlarında) okuyan çocukları olan Sinop'taki gönüllü elli anne oluşturmaktadır. Var olan bir durumu tanımlayan ya da gösteren yöntem olarak nitel araştırma yöntemi bu çalışmada kullanılmıştır (Karasar, 2008: 77). Araştırmada araştırmacı tarafından 
hazırlanan yarı yapılandırılmış görüşme formda tek ebeveynli çocukların sorunlarını anlamaya dönük dört farkı soru bulunmaktadır. Bu sorular:

“Çocuğunuzda gözlemlediğiniz genel sorunlar nelerdir paylaşa bilir misiniz?"

“Çocuğunuzun davranışlarına ilişkin sorunları nelerdir?"

"Çocuğunuzun duygularına ilişkin sorunları nelerdir?"

"Çocuğunuzun düşüncelerine ilişkin sorunları nelerdir?"

İlk basamak olarak ilgili literatürün taranmasıyla bir deneme formu oluşturulmuştur. İçinde psikologların da yer aldığı beş uzman soruları incelemiştir. Daha sonra sorular araştırmada yer almayan on anneye sorulmuş ortak anlaşılma düzeyi doğrultusunda ve uzman görüşleri de alınarak gerekli düzeltmeler yapılmış ve forum son şeklini almıştır. Yarı yapılandırılmış görüşme formu elli boşanmış anneye yöneltilmiş ve onlardan gelen cevaplar kaydedilmiştir. Alınan cevaplar içerik analiziyle çözümlenmiştir. İçerik analizi nitel araştırmalarda kullanılan bir analiz yöntemidir (Twycross ve Shields, 2008, p.38). İçerik analiziyle belirlenen dataların güvenilirliği aynı cevap sayfasının (tekst) farklı zamanlarda iki kez kodlanmasıyla yapılmıştır. Kategoriler arasında \%80lik bir kod uyumu kabul edilebilir olarak belirtilmektedir (Türnküklü, 2000). Kodlanan datalar ana temalar altında toplanmıştır. Temaların frekansları bulunmuştur. Bu frekanslara ilişkin yorumlar yapılmıştır.

\section{Bulgular}

Toplanan dataların analizine ilişkin frekanslar tabloda gösterilmiştir (Bkz. Tablo 1). Araştırmada elli boşanmış anneyle yapılan görüşmede ilk soru olarak "Çocuğunuzun genel sorunları nelerdir paylaşa bilir misiniz?" sorusu yöneltilmiştir. $\mathrm{Bu}$ soruya ilişkin araştırmaya katılan tüm anneler çocuklarında bazı sorunları gözlediklerini ancak bu sorunların boşanmış olmalarından $\mathrm{m}$ kaynaklanmış olduğunu yoksa tüm çocuklarda görülebilecek genel sıradan sorunlar mi olup olmadiğı konusunda bilgi sahibi olmadıklarını ifade etmiştir.

"Çocuğunuzun davranışlarına ilişkin sorunları nelerdir?" sorusuna karşın 22 anne çocuğunun içe kapanık olduğunu, 18 anne saldırgan olduğunu, 16 anne ise aşırı hareketli olduğunu belirtmiştir. Çocuklarının hem saldırgan hem de aşırı hareketli olmalarından dolayı öğretmenleri tarafından veli toplantılarında uyarılan anneler bu konuda uzman bir yardım almak için doktora başvurduklarını ifade etmiştir.

“Çocuğunuzun duygularına ilişkin sorunları nelerdir?" sorusuna araştırmaya katılan tüm anneler mutsuz cevabını vermiştir. 18 anne öfkeli, 16 anne ise üzgün cevabını vermiştir. Araştırmaya katılan 15 anne çocuklarının sıklıkla içe kapanık, dalgın, evde saatlerce konuşmadığını söylemiştir.

“Çocuğunuzun düşüncelerine ilişkin duyguları nelerdir? sorusuna 36 anne derslerinin kötü olduğunu, okul başarılarının düşük olduğunu, 28 anne evde çocuklarının ödevlerine gereken önemi vermediğini belirtmiştir. 12 anne ise boşanmadan dolayı çocuklarının kendilerini suçladığını belirtmiştir. 
Tablo 1: Eşinden Ayrılmış Annelerin Çocuklarının Problemlerine İlişkin Düşünceleri

\begin{tabular}{|c|c|c|c|}
\hline Temalar & Örnekler & Frekans & Yüzde \\
\hline \multirow{3}{*}{ 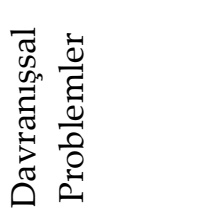 } & Çocuğum çok içine kapanık. & 22 & 44 \\
\hline & Çocuğum hırçınlaştı (saldırgan). & 18 & 36 \\
\hline & Aşırı hareketli kıpır kıpır yerinde duramıyor. & 16 & 32 \\
\hline \multirow{4}{*}{ 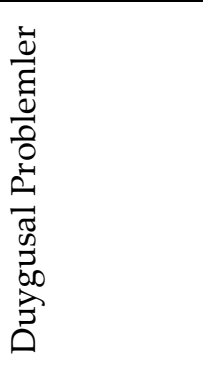 } & $\begin{array}{l}\text { Genellikle mutsuz. Katıla katıla güldüğünü } \\
\text { görmedim. }\end{array}$ & 50 & 100 \\
\hline & $\begin{array}{l}\text { Sık sık öfke nöbetleri geçiriyor. Kapıyı çarpıyor } \\
\text { masayı yumrukluyor. }\end{array}$ & 18 & 36 \\
\hline & $\begin{array}{l}\text { Üzgün olduğu her halinden belli. Onun bu } \\
\text { haline alıştık. }\end{array}$ & 16 & 32 \\
\hline & Oldukça dalgın, saatlerce boş boş bakıyor. & 15 & 30 \\
\hline \multirow{3}{*}{ 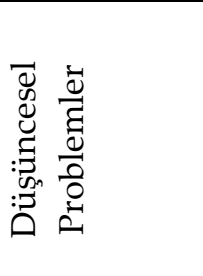 } & Derslerinde kötü başarısı çok düşük. & 36 & 72 \\
\hline & $\begin{array}{l}\text { Ödevleriyle ilgilenmiyor. Kendini vererek ders } \\
\text { çalıştı̆ını hiç görmedim. }\end{array}$ & 28 & 56 \\
\hline & $\begin{array}{l}\text { Boşanmadan dolayı suçluyor. Benimle o kadar } \\
\text { sık tartışıyor ki ne yapacağımı bilmiyorum. }\end{array}$ & 12 & 24 \\
\hline
\end{tabular}

Bu durumda eşlerinden ayrılmış elli annenin çocuklarına ilişkin sorunları üç genel tema altında toplanmıştır. Bu temalar davranışsal problemler, duygusal problemler ve düşüncesel problemlerdir. Problemlere ilişkin ifade frekansları ve bu ifadelerden bazı örnekler Tablo I de verilmiştir.

\section{Sonuç, Tartışma, Tavsiyeler}

Eşinden ayrılmış ilkokulda (6 ile 12 yaş) çocuğu olan ve bu araştırmada yer almış elli anne çocuklarının bir takım sorunları olduğunu belirtmiştir. Gerek yurt dışında yapılan gerekse Türkiye'de yapılan çalışmalar boşanmış tek ebeveynli ailelere mensup çocukların bir takım problemleri olduğu yöndedir (Karaoğlan, 1997; Çelikoğlu, 1998; Kuyucu, 1999; Şirvanl1-Özen, 1998; Erim, 2001; Elmac1, 2001; Özcan, 2005; Akduman ve diğerleri, 2007; Blake, 1981; Block ve diğerleri, 1986; Kalter ve diğerleri, 1985; Frost ve Pakiz, 1990; Amato ve Keith, 1991; Liu, 2003). Bu çalışmanın bulguları da gerek yurt içi gerekse yurt dışı çalışmalarıyla paralellik göstermektedir. Ancak Weitoft ve diğerleri, (2003)'nin çalışmalarında ifade edilen çocuklarda bulunan istenmeyen eğilimler bu çalışmada yer alan anneler tarafından belirtilmemiştir. Bunun dışında Buckner ve Bassuk, (1999) çalışmalarında olduğu gibi çocukların aşırı anksiyetede olduğunu gösteren sonuçlara da bu çalışmada rastlanılmamıştır.

Davranışsal olarak aşırı aktiflik Mokrue ve diğerleri, (2012) çalışmalarında olduğu gibi bu çalışmada da mevcuttur. Düşük akademik başarı annelerin yakındığ bir konudur ve (Shelton (1969; Savage, 1980; Özgüven, 2001) çalışmalarında da aynı konuya dikkat çekilmiştir. 
O'Rourke ve Worzbyt, (1996), Baris ve Garrity, (1988), Johnson ve Roseby, (1997) Wallerstein ve Blakeslee, (2003) çalışmaları tekrar incelenecek olursa bu çalışmalarda burada yapılmış çalışmanın yaş dilimi olan 6 ile 12 yaş grubu çocuklarında boşanmadan sonra görülen problemler şu şekilde özetlenebilir: Ebeveynlerin belirttiğinden kendi ihtiyacını ayırmada güçlük, üzgün, kayıp, korku, belirsizlik hissi, yaygın anksiyete, dağınık ve tedirgin, okul çalışma problemleri, terk duyguları ebeveynleri özlem onları fazla görememe, algılanan redde öfke, koruyucu aileye, öğretmene ve diğer çocuklara saldırı, reddedilme, kendini suçlama, yabancılaşmış hissi, güvenlik için diğer yetişkinlere bağlanma, kaybolma hissi, reddedilmiş, çaresiz, yalnız, utanma, sıkılma hissi, ebeveyn benzeri davranış kontrolünde güçsüzlük, öfke, çekinme, aşırı aktif, boşanmadan dolayı bir ebeveyni suçlama doğrudan öfke, okul çalışma problemleri, karmaşık başlılık, yalnızlık, depresyon duygularıyla mücadele, otoriteyle güç mücadelesi, ev dışındaki diğer yetişkinlerden destek arayabilme şeklinde tek ebeveynli çocukların problemleri sıralanmaktadır. Anneler çocuklarının problemlerini belirlemede uzman değillerdir. Ancak ifadelerden de anlaşılmaktadır ki aşırı hareketlilik bir hiperaktivite, içe kapanıp saatlerce konuşma anksiyete belirtileri olabilir.

Sonuç olarak tüm dünyada olduğu gibi Sinop'lu eşlerinden ayrılmış annelerin çocukları da boşanmanın istenmeyen sonuçlarına katlanmaktadır. Ortak sorunlar bellidir. Bundan sonra okul yöneticileri, öğretmenler ve okullarda görevli psikolojik danışman ve rehber öğretmenler parçalanmış ailelerden gelen çocuklara karşı daha duyarlı olmaları tavsiye edilmektedir. Boşanmış anneler çocuklarının sorunlarına karşı bilgilendirilmeli ve bu sorunlara karşı ev ortamında nasıl müdahale edebilecekleri konusunda eğitim almaları gerekmektedir. Bu durumda okul aile işbirliğinin önemi kaçınılmaz olmaktadır.

$\mathrm{Bu}$ çalışmada nitel araştırma yöntemlerinden görüşme kullanılarak ilkokulda çocuğu olan elli anneden çocuklarına ilişkin sorunlar irdelenmiştir. İleriki çalışmalar okul öncesi, ortaokul, lise hatta ekonomik zorlukların oluşturduğu problemler, aile bakış açısının değerlendirilebileceği üniversite kademesinde bulunan parçalanmış ailelerden gelen öğrenciler üzerine yürütülebilir. Evde sadece annenin varlığı ya da sadece babanın varlığı ayrı ayrı kız ya da erkek çocuklar üzerine nasıl etki bıraktığı başka bir çalışmanın konusu olabilir. Tüm bu çalışmalar sonucunda parçalanmış ailelerden gelen çocukların problemlerini azaltma konusunda müdahale yöntemleri üzerine yapılacak çalışmalara da ihtiyaç vardır.

\section{Kaynakça}

Akduman, G., Akduman, B. ve Cantürk, G. (2007). Ergen Suçluluğunda Bazı Kişisel ve Ailesel Özelliklerin İncelenmesi" Ankara Üniversitesi Tıp Fakültesi Adli Tıp Ana Bilim Dalı Çocuk İstismarı Araştırma Birimi, Türk Pediatri Arşivi, 42 (4), 156-161.

Amato, P. R., \& Gilbreth, J. G. (1999). Nonresident fathers and children's well-being: A metaanalysis. Journal of Marriage and the Family, 61, 557-573.

Amato, P.R. (2005). The impact of family formation change on the cognitive, social, and emotional well-being of the next generation. Future of Children 15(2), 75-96. 
Amato, P.R. ve Keith, B. (1991). Parental Divorce and Adult Well-Being: A Meta Analysis, Journal of Marriage and the Family, 53, 43-58.

Baris, M. A., ve Garrity, C. B. (1988). Children of divorce: A developmental approach to residence and visitation. Illinois: Psytec Corporation.

Bell, R. R. (1981). Worlds of friendship. Beverly Hills, CA: Sag.

Benedek, E. ve Brown, C. (1997). Boşanma ve Çocuğunuz (Çev. S. Katlan), Hyb Yayıncılık, Ankara.

Blake, J. (1981). The only child in America: Prejudice versus performance. Population and Development Review, 7,43-54.

Block, J. H., Block, J. ve Gjerde, P. F. (1986). The Influence of Parenting Style on Adolescent Competence and Substance Abuse, Journal of Early Adolescence, 11, 56-94.

Buckner, J. C. ve Bassuk, E. L. (1999). Homelessness and its relation to the mental health and behavior of low-income school-age children. Developmental Psychology, 35, 1 246-258.

Carlson, M. J. ve Corcoran, M. E. (2001). Family structure and children's behavioral and cognitive outcomes. Journal of Marriage and the Family, 63, 779-792.

Collins, A. W. (1990). Parent-child relationships in the transition to adolescence: Continuity and change in interaction, affect, and cognition. In R. Montemayor, G. R. Adams, ve T. P. Gullotta (Eds.), Advances in adolescent development: From childhood to adolescence: A transitional period? (pp. 85-106). Newbury Park, CA: Sage.

Çelikoğlu, C. (1997). Boşanmanın Çocukların Benlik Saygısına Etkisinin İncelenmesi”, Doktora Tezi, Hacettepe Üniversitesi Sağlık Bilimleri Enstitüsü, Ankara.

Demo, D. H. ve Acock, A. C. (1988). The Impact of Divorce on Children. Journal of Marriage $\mathcal{E}$ Family, 50, 3 619-648.

Douvan, E., ve Adelson, J. (1966). The adolescent experience. New York: Wiley.

Dunn, J., Deater-Deckard, K., Pickering, K., ve O'Connor, T. G. (1998). Children's adjustment and prosocial behaviour in step-, single-parent, and non-stepfamily settings: Findings from a community study. Journal of Child Psychology and Psychiatry, 39, 1083-1095.

Ekşi, A. (1990). Çocuk, Genç, Anne Babalar, Bilgi Yayınevi, Ankara.

Elmacı, F. (2001), “Parçalanmış ve Bütünlüğünü Koruyan Aileye Sahip Ergenlerin Depresyon ve Uyum Düzeylerinde Sosyal Desteğin Rolü", Yüksek Lisans Tezi, Kocaeli Üniversitesi Sosyal Bilimler Enstitüsü, Kocaeli.

Erim, B. (2001), "Yetiştirme Yurtlarında ve Aileleri Yanında Yaşayan Ergenlerin, Benlik Saygısı, Depresyon ve Yalnızlık Düzeyleri ile Sosyal Destek Sistemleri Açısından Karşılaştırılması", Yüksek Lisans Tezi, Ankara Üniversitesi Sosyal Bilimler Enstitüsü, Ankara.

Feldman, S. S., \& Wentzel, K. R. (1990). Relations among family interaction patterns, classroom self-restraint, and academic achievement in preadolescent boys. Journal of Educational Psychology, 82, 813-819.

Ghysels, J. ve Van Vlasselaer, E. (2008). Child Well-Being in Flanders: A Multidimensional Account, Social Indicators Research, 89, 2 283-304. 
helps. Cambridge, Mass.: Harvard University Press.

Herwig, J. E., Wirtz, M., ve Bengel, J. (2004). Depression, partnership, social support, and parenting: Interaction of maternal factors with behavioral problems of the child. Journal of Affective Disorders, 80, 199-208.

Jackson, A.P. (2000). Maternal self-efficacy and children's influence on stress and parenting among single black mothers in poverty. Journal of Family Issues, 21, 3-16.

Jaffee, S. R., Moffitt, T. E. Caspi, A. and Taylor, A. (2003). Life With (or Without) Father: The Benefits of Living With Two Biological Parents Depend on the Father's Antisocial Behavior. Child Development 74, 1 109-126.

Johnston, J. R., ve Roseby, V. (1997). In the name of the child: A developmental approach to understanding and helping children of conflicted and violent divorce. New York: The Free Press.

Jonsson, F. H., Njardik, U., Olafsdottir, G. ve Gretarsson, S. J. (2000). Parental divorce: Longterm effects on mental health, familiy relations and adult sexual behavior, Scandinavian Jornal of Pschology, 41 101-105.

Kalter, N., Riemer, B., Brickman, A., \& Chen, J. W. (1985). Implications of parental divorce for female development. Journal of the American Academy of Child Psychiatry, 24, 538-544.

Karaoğlan, B. (1997) Boşanmanın Gencin Kişiliğine Etkisi", Yüksek Lisans Tezi, Cumhuriyet Üniversitesi Sosyal Bilimler Enstitüsü.

Karasar, N. (2008). Bilimsel Araştırma Yöntemi: Kavramlar, İlkeler, Teknikleri, (18. Baskı), Ankara: Nobel.

Kuyucu, Y. (1999). Anne Babaları Boşanmış ve Birlikte Yaşayan Lise Öğrencilerinin Uyum Sorunlarının Karşılaştırılması Üzerine Bir İnceleme, Yüksek Lisans Tezi, Dokuz Eylül Üniversitesi Eğitim Bilimleri Enstitüsü, İzmir.

Lamb, M. E. (1997). Fathers and child development: An introductory overview and guide. In M. E. Lamb (Ed.), The role of the father in child development (3rd ed., pp. 1-18). New York: Wiley.

Liu, Y. (2003). Parent-Child Interaction And Children's Depression The Relationships Between Parent-Child Interaction And Children's Depressive Symptoms In Taiwan, Journal of Adolescence. 26 (4), 447.

McLanahan, S. ve Booth, K. (1989). Mother-Only families: Problems, Prospects, and Politics. Journal of Marriage \& Family, 51, 3 557-580.

McLanahan, S., \& Sandefur, G. D. (1994). Growing up with a single parent: What hurts, what helps. Cambridge, Mass.: Harvard University Press.

Mokrue, K, Chen, Y. Y, Elias, M. (2012). The Interaction between Family Structure and Child Gender on Behavior Problems in Urban Ethnic Minority Children. International Journal of Behavioral Development 36, 2 130-136.

Montemayor, R. (1986). Family variation in parent-adolescent storm and stress. Journal of Adolescent Research, 1,15-31.

Moore, K.A., Vandivere, S., ve Redd, Z. (2006). A sociodemographic risk index. Social Indicators Research, 75, 45-81. 
Morganett, S.R. (2005). Yaşam Becerileri Ergenler İçin Grupla Psikolojik Danışma Uygulamaları, (Çev. S. Gürçay, S., Kaya, A. ve Saçkes, M.), PegamA Yayıncılık, Ankara.

Nazlı, S. (2003). Aile Danışmanlı̆̆ı (2.Baskı), Ankara: Nobel.

O'Connor, T. G., Dunn, J., Jenkins, J. M., Pickering, K., ve Rabash, J. (2001). Family settings and children's adjust-ment: differential adjustment within and across families. British Journal of Psychiatry, 179, 110-115.

O’Rourke, K., ve Worzbyt, J. C. (1996). Support groups for children. Philadelphia, PA: Accelerated Development.

Özcan, B. (2005). Anne-Babaları Boşanmış ve Anne-Babaları Birlikte Olan Lise Öğrencilerinin Yılmazlık Özellikleri ve Koruyucu Faktörler Açısından Karşılaştırılması", Yüksek Lisans Tezi, Ankara Üniversitesi Eğitim Bilimleri Enstitüsü, Ankara.

Özgüven, İ.E. (2001). Ailede İletişim ve Yaşam, Ankara: PDREM Yayınları.

Öztürk, M. S. (2012). Tek ebeveynli ailelerin yaşadıkları ekonomik güçlüklerin incelenmesi Hacettepe Üniversitesi Sosyal Bilimler Enstitüsü Yayınlanmamış Yüksek Lisans Tezi.

Pettit, G. S., Yu, T., Dodge, K. A. ve Bates, J. E. (2009). A Developmental Process Analysis of Cross-Generational Continuity in Educational Attainment, Merrill-Palmer Quarterly: Journal of Developmental Psychology, 55, 3 p250-284.

Sandefur, G. D., Mclanahan, S. ve Wojtkiwicz, R. A. (1992). The Effects of Parental Marital Status during Adolescence on High School Graduation, Social Forces, 71, 1 103-121.

Savage, D. C. (1980). One-Parent Families. Education Digest, 46, 263.

Schaie, K. W. \& Willis, S. L. (1996). Adult development and ageing (4th ed). New York: Haper Collins.

Shelton, L. A. (1969). A comparative study of educational achievement in one- parent and in two-parent families (Doctoral dissertation, University of South California.

Soyaslan, D., (1998). Kriminoloji (suç ve ceza bilimleri) Ankara: Ankara Üniversitesi Hukuk Fakültesi Yayınları No.526.

Şentürk, Ü. (2006), “Parçalanmış Aile Çocuk İlişkisinin Sebep Olduğu Sosyal Problemler (Malatya Uygulaması)", Doktora Tezi, İnönü Üniversitesi Sosyal Bilimler Enstitüsü Sosyoloji Ana Bilim Dalı, Malatya.

Şirvanlı-Özen, D. (1998), “Eşler Arası Çatışma ve Boşanmanın Farklı Yaş ve Cinsiyetteki Çocukların Davranış ve Uyum Problemleri ile Algıladıkları Sosyal Destek Üzerindeki Rolü", Doktora Tezi, Hacettepe Üniversitesi Sosyal Bilimler Enstitüsü, Ankara.

Thomas, A. ve Waddell D. (1990). Children and Divorce Scholl Psycology Review, by Shoran W. Royal and Howard, M.Knoff University of South Florida Tapma, 19 (2), 253.

TÜIK, (2010). T.C. Başbakanlık Türkiye İstatistik Kurumu Haber Bülteni, Evlenme ve Boşanma İstatistikleri 2010 Yılı III . Dönemi. 227.

Türnüklü, A. (2000). Eğitimbilim Araştırmalarında Etkin Olarak Kullanılabilecek Nitel Bir Araştırma Tekniği: Görüşme. Ĕ̆itim Yönetimi, 6, 4, (543-559).

Twycross, A.; Shields, L. (2008). Content analysis. Paediatric Nursing 20 (6) p. 38. 
Uluğ, M. ve Candan, G. (2008), "Parçalanmış (Boşanmış) Aile Sorununun Öğrenciye Etkisi", İstanbul Kültür Üniversitesi Fen-Edebiyat Fakültesi Psikoloji Bölümü, Eğitim Psikolojisi Sempozyumu, 22-23 Mart, İstanbul.

Uluğtekin, S. (1991). Hükümlü Çocuk ve Yeniden Toplumsallaşma, Bizim Büro Yayınları, Ankara.

Wallerstein, J. S. ve Blakeslee, S. (2003). What about the kids?: Raising your children before, during, and after divorce. New York: Hyperion.

Wallerstein, J. S., \& Kelly, J. B. (1980). Surviving the breakup: How parents and children cope with divorce. New York: Basic Books.

Wallerstein, J. S., Lewis, J., ve Blakeslee, S. (2000). The unexpected legacy of divorce: A 25 year landmark study. New York: Hyperion.

Wallerstein, J. S., ve Lewis, J. (1998). The long-term impact of divorce on children: A first report from a 25-year study. Family and Conciliation Courts Review, 36, 368-383.

Warshak, R. A. (2000). Social science and children's best interests in relocation cases: Burgess revisited. Family Law Quarterly, 34, 83-113.

Weitoft, G. R., Hjern, A. Haglund, B. ve Rosen, M. (2003). Mortality, severe morbidity and injury in children living with single parents in Swede: a population-based study. Lancet, 361, 289-295.

Weyburne, D. (2000). Ben Şimdi Ne Olacağım?, (Çev. H. Koşar), Kuraldışı Yayıncılık, İstanbul.

Wolf, A. E., (1998). Boşanmanız Şart mıydı?, (Çev. E. Aksoy), Sistem Yayıncılık, Ankara.

www.childtenrs.org (25.12.2012 erişim).

Yavuzer, H. (2001). Çocuk Psikolojisi, (20. Bask1), Remzi Kitabevi, İstanbul.

Youniss, J,, ve Smollar, J. (1985). Adolescent relations with mothers, fathers, and friends. Chicago: University of Chicago Press.

Yörükoğlu, A. (2004). Çocuk Ruh Sağllğı (27. Baskı), Özgür Yayınları, İstanbul. 